\title{
Project Management and Strategic Objectives of the Organization
}

\author{
Sarbjit Singh \\ Operations Management, Institute of Management Technology, India
}

Copyright $\mathrm{C} 2017$ by authors, all rights reserved. Authors agree that this article remains permanently open access under the terms of the Creative Commons Attribution License 4.0 International License

\begin{abstract}
Once the vision and mission of any organization is finalized the next step for them to formulate the road map to achieve that vision and mission. One of the ways is to derive strategic objectives which aid the organization to achieve its vision and mission. Generally these strategic objectives are for short term in comparison to the laid vision and mission. This study shows how projects help to achieve these strategic objectives. It also provides some examples where financial feasibility might not be the only criteria for selection of projects.
\end{abstract}

Keywords Strategic Objectives, Work-breakdown Structure, Responsibility Matrix, Network Analysis

\section{Introduction}

Projects have become a part and parcel for most of the organizations today. Two decades back projects were rare and only few organizations used to use project management techniques. Most of the project management literature is on completing the project on time and within budget and according to specifications performance Keren et Cohen, [1] Rozenes et al. [2]. Project management revolves around three aspects i.e. cost, time and scope. But this scope can be defined to achieve strategic objectives of the organization. Freeman M. and Beale [3] worked on measuring the project success, thus successfully completing project will imply the attainment of the strategic goals. Also mapping the dimensions of the project success has been proposed by Shenhar, Levo and Dvir, [4].

The strategic importance of the project is typically obtained only after the project is done. For example, even if project outputs have been delivered efficiently the project can still be ineffective to the funding organization. Examples are the Sydney cross-city tunnel Zwikael and Smyrk, [5] and the Los Angeles Metro Shenhar and Dvir, [6] Another well-known example is the famous Sydney opera building which was far from being on time and on budget, but is a great success for the long run. Recently, a wider view on the management of projects has emerged, which also discusses the delivery of strategic goals by projects Gareis and Stummer, [7]. Morris and Jamieson [8]. Cleland, D.I. [9] has given emphasis on the strategic design and implementation in project management

Project benefit management research emphasizes the strategic roles of projects in organizations. e.g., Kolltveit et al., [10] and defines the benefit of management process e.g., Breese, [11]. Consequently, benefit management is becoming an important research area. Gareis $\mathrm{R}$. and Huemann M, [12] has emphasized on the project management competencies in the project-oriented organization. One of the important requirements of the successful project is attachment of the project sponsor with the project, Kloppenborg, Timothy, Chris and Debbie [13] has mentioned in their paper on successful project sponsor behavior during project initiation. They [14] further investigated the role of project sponsor in project planning.

Project benefits are "the flows of value that arise from a project" Zwikael and Smyrk, [15]. A project owner is accountable to the project funder/founder for the realization of these target benefits. In this paper we lay a conceptual framework for the interface between a project and its strategic considerations. This study emphasizes on the use of project management to achieve the organizations mission and vision.

\section{How Strategy Is Implemented through Projects}

The diagram below shows that Strategic analysis which helps the organizations to develop their guidelines i.e. Vision and Mission for the organization and which can broke down to strategic objectives, which should be specific, concrete and are in measurable terms.

Characteristics of Objectives (Doran, [16])

S Smart Be Specific in targeting an objective

M Measurable Establish a measurable indicator(s) of progress

A Assignable Make the objective assignable to one 
person for completion

R Realistic State which can realistically be done with available resources

$\mathrm{T}$ Time related State when the objective can be achieved, that is duration

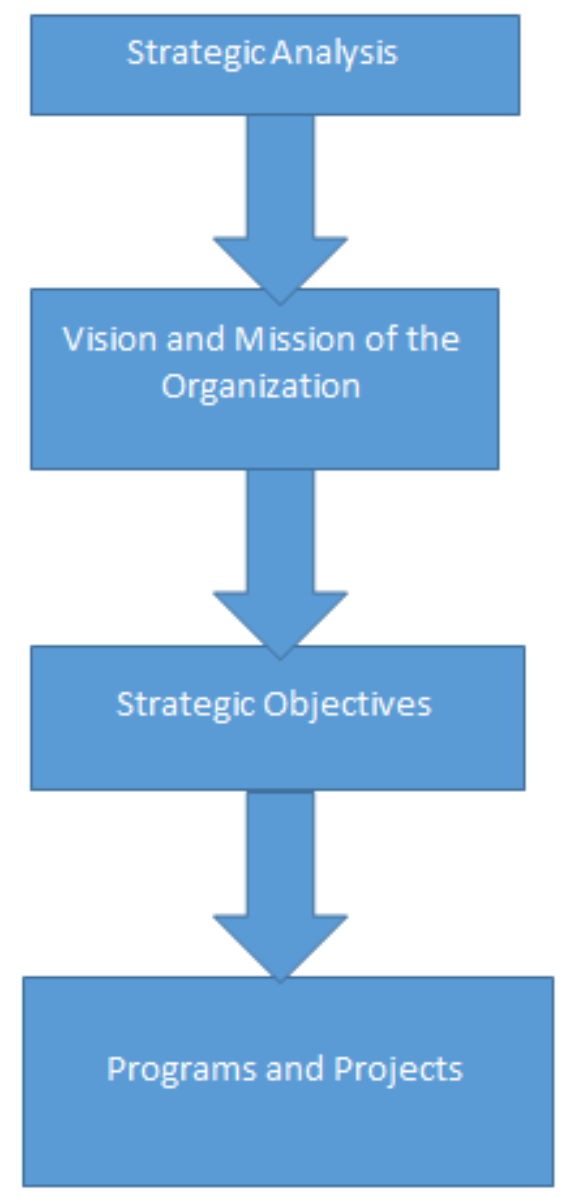

Diagram 1.

One of the major crux organization faces is to achieve the objectives with the limited available resources. Some of the resources are always tied with the operational issues and they cannot be fully utilized for achieving the set objectives of the organization. In this situation of crunch projects are treated as addendum rather than an integral part of strategy.

If organization converts these strategic objectives as projects than action plan to achieve these objectives can be achieved by project management. The tools of project management like work break down structure (dividing the work into small work elements), responsibility matrix (making person responsible for each of the assigned work element) and network analysis (constructing a network flow diagram of the whole project and find out the duration of the project using critical path method) will resolve the problems like who will do what and by when we can achieve the desired goals.

Also the monitoring techniques will also help to keep tap on the required objectives and what change will happen on implementation of these projects. Keeping track of the schedule it helps to monitor whether the strategy can be implemented by due date or not. In other words we can check whether we are on the right track to achieve our mission and vision.

The other aspect of the project management is risk management which helps organization to study the barriers or resistance and also provide the plan to overcome them. Thus it helps organization to be ready for any undue deviation from the project plan.

\section{Examples Where Projects Have Been Used to Achieve Strategic Objectives}

The case Intrapreneurship at Alcatel-Lucent (Simon Parket [17]) is one of the example were projects have been used to achieve organizations strategic objectives. Even many of the countries welfare schemes which can be considered as government strategic objectives are achieved using different programs and projects. There are many examples where projects have been deployed to achieve strategic objective and hence were helpful for organization to accomplish their mission and vision.

\section{Conclusions}

Every organization has set its mission and vision and they work to achieve these in due course of time. One of the way is strategic planning process to achieve these long term goals i.e., formulation of well-defined strategic objectives to achieve the desired mission and vision. This strategic planning helps to achieve the set goals. The study shows how project management can be used to achieve these strategic goals. This study also mentioned about the tools and techniques of the project management which can be used to achieve and monitor the ascertained projects to achieve strategic objectives.

\section{REFERENCES}

[1] Keren, B., Cohen, Y. (2012), “Optimizing Project Performance: The Triangular Trade-off Optimization Approach", International Journal of Engineering Management and Economics (IJEME), Vol. 3, No. 1, pp. 152-170.

[2] Rozenes, S., Vitner G., Spraggett S. (2006), "Project Control: Literature Review”, Project Management Journal, vol. 37, No. 4, pp.5-14.

[3] Freeman, M. and Beale, P. (1992), "Measuring project success," Project Management Journal, Vol.23 (1), pp. 8-17.

[4] Shenhar, A.J., Levy, O., and Dvir, D. (1997) "Mapping the dimension of project success", Project Management Journal, vol. 28(2), pp. 5-13

[5] Zwikael, O., Smyrk, J.R. (2011), Project Management for the 
Creation of Organizational Value. Springer-Verlag, London.

[6] Shenhar, A.J., Dvir, D. (2007), Reinventing Project Management: The Diamond Approach to Successful Growth and Innovation. Harvard Business School Press, Boston, MA.

[7] Gareis, R., and Stummer, M. (2008), Processes and Projects, Manz, Vienna.

[8] Morris, P.W.G., Jamieson, A. (2008), “ Implementing strategy through programs of projects, In Turner, J.R. (Ed.), Gower Handbook of Project Management, 4th ed. Aldershott, Gower.

[9] Cleland D.I. (1994), Project Management: Strategic Design and Implementation. New York: John Wiley and Sons.

[10] Kolltveit, B.J., Karlsen, J.T., Grønhaug, K. (2007),” Perspectives on project management". International Journal of Project Management, Vol. 25, pp. 3-9.

[11] Breese, R. (2012), "Benefit realization management: panacea or false dawn?" International Journal of Project Management, Vol. 30, pp. 341-351.

[12] Gareis R., and Huemann, M. (2000), "Project Management competencies in the project-oriented organization", Project Management Journal, Vol.31 (1), 32-43.

[13] Kloppenborg, Timothy J., Chris Manolis and Debbie Tesch, (2009) "Successful Project Sponsor Behavior During Project Initiation: An Empirical Investigation" Journal of Management Issues Vol. 21(1), 140-159.

[14] Kloppenborg, Timothy J., Chris Manolis and Debbie Tesch, (2010) "Investigation of Sponsor Role in Project Planning," Management Research Review, Issues Vol. 34(4), 400-416.

[15] Zwikael, O., Smyrk, J.R. (2012), “A general framework for gauging the performance of initiatives to enhance organizational value", British Journal of Management, Vol. 23, pp. S6-S22.

[16] Doran, G.T., "There's a Smart Way to Write Management Goals and Objectives," Management Review, November 1981, pp. 35-36.

[17] Simon Parke, (2015) "Intrapreneurship at Alcatel-Lucent", Ivey Publishing, W14642 